\title{
A Comparative Analysis of the Seasonal Trends in India and Other Markets of the BRICS Nations
}

\author{
Effulgence \\ Vol. 16 No. 1 (Special Issue 2) \\ January - June, 2018 \\ Rukmini Devi Institute of Advanced Studies \\ E-mail : effulgence@rdias.ac.in, Website : www.rdias.ac.in \\ http://effulgence.rdias.ac.in/user/default.aspx \\ https://dx.doi.org/10.33601/effulgence.rdias/v16/iSpl2/2018/14-26
}

\section{Ananya Sharma ${ }^{1}$ \\ Dr. Rakesh Shahani ${ }^{2}$}

\begin{abstract}
The present study makes an attempt to investigate the seasonal trends in India and other BRICS nations by using 'calendar effect- month of the year' methodology. The data for the purpose of the study includes log transformed monthly returns of the major stock market indices of the five BRICS nations for the ten year period April 2007 to March 2017. The techniques employed for testing the 'month of the year' effect include Hypothesis Testing using Dummy Approach (without intercept OLS Regression $\mathcal{E}$ also with Newey West Regression Robust test) Other techniques used in the study include GARCH $(p, q)$ Methodology for identifying month of the year impact in mean and variance equations \& TGARCH $(p, q)$ Methodology for identifying "asymmetry in month of the year returns". The study results based upon OLS Dummy without Intercept clearly showed that BRAZIL's IBOVESPA index had significant mean returns in the months of April. Also results using OLS Newey West showed that BRAZIL's IBOVESPA index continued to be significantly different for the month of April while Coefficient for S. Africa's Dummy was significant for the month of June. The Dummy coefficient was insignificant for rest of the indices. The GARCH $(p, q)$ equation was fitted which showed that BRAZIL's IBOVESPA index Dummy to be significantly different in the month of May when regressors were included only in the mean equation, while it was May and Nov being significant in mean equation $\mathcal{E}$ only Nov as significant in variance equation when regressors were included in both mean and variance equations. Also when regressors were included in both mean and variance equations, significant dummy was also seen in $S$ Africa in the months of June, \& March \& China in the months of Sept $\mathcal{E}$ Feb. The T GARCH term showing asymmetric volatility for good and bad news was significant for $S$ Africa and Brazil indices only.
\end{abstract}

Keywords: BRICS, Newey-West Robust Regression, GARCH(p,q), T-GARCH(p,q) ADF Stationarity tests.

\section{INTRODUCTION}

Seasonal Patterns in Stock Returns (also called anomalies is today one of the more sought after research areas in academic circles. The research is also important from the angle of a stock investor who is always in the look- out for profitable trading opportunities by way of exploring the inefficiencies of the market. Now if an investor can identify any

1. Student, BA (H) Business Economics, Dr.Bhim Rao Ambedkar College (University of Delhi), ananyasharma1397@gmail.com

2. Associate Professor, Business Economics, Dr.Bhim Rao Ambedkar College (University of Delhi), rakesh.shahani@gmail.com (also the corresponding author) 
specific day in a week (or any particular month in a year) which gives a return different (say significantly higher or significantly lower than the average return) from other days (or months), he is said to have encashed this anomaly and such a market ceases to be an efficient market.

The empirical research on US Markets on seasonal patterns has shown that the stock return on Monday is significantly higher while stock return on Friday is significantly lower than the other days of the week (French (1980), Gibbons \& Hess (1981), Rogalshi (1984). There are many theories behind such abnormal returns \& one of the most popular theories is that the Abnormal Returns on Monday could be attributed to Compounding Effect of three Days Return. On the other hand some studies (Jaffe \& Westerfield (1985A) have pointed out that in some countries the abnormal high returns are on Tuesday's rather than Monday's e.g. in Australia, the high returns are seen on Tuesday's, one the possible explanation could be the time difference between US \& Australian Market. On the other hand F. Guidi, R. Gupta and S. Maheshwari (2011) found that most of the markets in Central and Eastern Europe did not exhibit the any day of the-week effect.

Also there is also no dearth of literature on testing seasonal patterns or calendar effect with respect to month of the year returns. Amongst the monthly effect, the January effect and December Effect are popular amongst the researchers. January Effect was popularized by Rozeff \& Kinney (1976). Many studies have shown that markets throughout the world go up early January and the reverse happens during the month of December (Surbhi, et.al (2014)). The prominent studies amongst the month of the year include Marrett \& Worthington (2011) who found calendar effect in months of April, July \& December for Australian Market. Ignatius (1998) found existence of December Effect. The studies on Indian Markets include Kaur (2004) who found the months of March \& September reported lower returns while February \& December generated higher than average returns also Fountas and
Segredakis (2002) found that for India, returns for the month of August stood apart from some of the other months. On the other hand, BodlaandJ. (2006) failed to find any seasonality effect in the returns on Indian stocks (1998 to 2005). Similarly Chia, R et.al (2006) found no monthly effect for the Malaysian Market. Some studies have investigated six monthly mean returns e.g. Patel and Evans (2003)found that all G7 nations had their mean stock returns for six months; December to May as significantly higher than mean returns for next six months. Keppler and Xue (2003) also found for eighteen developed markets substantially higher returns for six months; November to April over the next six months May to October.

A glance at the research studies mentioned above on the seasonal patterns in stock returns would surely point out to one important question "Are these differences a mere illusion which have occurred due to different type of biases or due to sampling/statistical errors during analysis of data or do these differences actually point to market inefficiencies as revealed by study results duly supported by researchers explanation". The above statement is important since most of the econometric techniques used by the researchers revolve around the collection of data, period of study \& assumptions made with respect to model tested. Further the accuracy level of $95 \%$, still keeps a margin of $5 \%$ for errors.

Considering the above aspects, our study has been designed to investigate the seasonal trends in India and other BRICS nations by using 'calendar effectmonth of the year' methodology. The data for the purpose of the study includes log transformed monthly returns of the major stock market indices of the five BRICS nations for the ten year period April 2007 to March 2017 obtained from websites; www.nseindia.com, www.jse.co.za, www.investing. com. The rest of the paper is structured as follows: Section II: gives information about the sampled indices. Section III: describes the Statistical Description of Data \& Diagnostic tests undertaken, 
Section IV: discusses the methodology employed along with hypothesis to be tested Section: V: provides empirical results of the study \& its interpretation \& finally Section VI: gives the conclusion.

\section{About the Sampled Indices}

The sample includes stock indices of five emerging economies namely Brazil, Russia, India, China \& South Africa which have pooled themselves into one regional Bloc popularly called BRICS. Table I given below gives the details of these five stock indices. If we talk of the regional Bloc BRICS, the said acronym was initially called 'BRIC' and came to light when a research paper was brought out by Goldman Sachs in 2001which had a mention of four potential economic powerhouses namely Brazil, Russia, India and China. The BRIC Bloc slowly gained popularity and after ten years of its existence in 2010, this group was joined by South Africa \& the name was thus changed to BRICS (Exim Bank (2014)) The BRICS Bloc became popular as all the countries in the Bloc had some common features like presence of abundant natural resources, had a large agrarian base and there was fast evolving service sector in all the five economies. BRICS Bloc enjoys a combined population of $40 \%$ of the World's population, contribute $18 \%$ to the global trade \& $25 \%$ to the World's GDP (Exim Bank 2014).Each of the nations of the BRICS group has a fairly developed stock market. Also all the markets of the BRICS nations has a different story of how it has achieved its sustained growth rate. (Mahajan A, Saluja, P \& Rakesh Shahani. 2014)

Table 1 : Sampled Stock Markets of BRICS and their Indices

\begin{tabular}{|l|c|l|}
\hline Sr. No & Country & Stock Market \& Index \\
\hline $\mathbf{1}$ & India & National Stock Exchange (CNX NSE Nifty) \\
\hline $\mathbf{2}$ & Brazil & Sao Paulo Stock Exchange ( IBOVESPA) \\
\hline 3 & Russia & Moscow Stock Exchange (Russian Trading Stock (RTS)) \\
\hline 4 & China & Shanghai Stock Exchange (SSE Composite Index) \\
\hline 5 & $\begin{array}{l}\text { South } \\
\text { Africa }\end{array}$ & Johannesburg Stock Exchange(FTSE/JSE Top 40 Index) \\
\hline
\end{tabular}

\section{Statistical Description of Data and Diagnostic tests}

The Statistical Description of our variables (viz. monthly return on all five BRICS indices) for the period of 10 years; April 07- March 2017 (119 observations per economy, returns data) is given in Table II below. The computations include Mean, Variance, Standard Deviation, Skewness \& Kurtosis. The table also includes computation of two diagnistic tests of our indices i.e. a test for normality (JB Statistics) \& a test of Stationarity (ADF Unit Root test). If we look at the table II then we find that out of five indices, the return on NSE Nifty of India showed the highest monthly mean return for the sampled period while SSE Composite China's Index showed the highest risk in terms of returns (or the variance of returns). In terms of the distribution of returns, none of the markets was found to be normally distributed (Normal JB* $<5.99$ ), on the other hand the skewness (or fat end tails) of all the markets was found to be negative. The return stationarity of all the markets was found out using $\mathrm{ADF}$ unit root test (with intercept and trend) and all were found to be stationary at levels. 
Table II: Statistical Description of our BRICS indices (Monthly Returns)(April 2007- Mar 2017)

\begin{tabular}{|c|c|c|c|c|c|}
\hline Stock Index & NSE NIFTY & CHINA & RUSSIA & $B R A Z I L$ & S. $A F R I C A$ \\
\hline No. of Observations $(n)$ & 119 & 119 & 119 & 119 & 119 \\
\hline $\operatorname{Mean}(\mu)$ & 0.009 & 0.002 & 0.004 & 0.005 & 0.006 \\
\hline Skewness(s) & -0.388 & -0.452 & -0.653 & -0.153 & -0.069 \\
\hline Kurtosis(k) & 5.300 & 0.551 & 3.160 & 0.887 & 1.116 \\
\hline Std Deviation $(\sigma)$ & 0.069 & 0.082 & 0.078 & 0.067 & 0.048 \\
\hline Variance $\left(\sigma^{2}\right)$ & 0.005 & 0.007 & 0.006 & 0.004 & 0.002 \\
\hline${ }^{*} J \mathbf{B}$ Statistic JB = & 29.209997 & 33.783382 & 8.584129 & 22.60862 & 17.70019 \\
\hline $\begin{array}{c}\text { Stationary (Details in } \\
\text { appendix) }\end{array}$ & Level** & Level & Level & Level & Level \\
\hline
\end{tabular}

\section{Research Methodology \& Hypothesis Testing}

The present study aims at investigating 'Month of the Year' effect in the economies comprising BRICS block for ten year period viz. April 1, 2007 to March 31, 2017. The study employs the following methodology for this purpose:

(a) Hypothesis Testing using Dummy Approach (without intercept OLS Regression)

(b) Hypothesis Testing using Dummy Approach (without intercept with Newey West Regression Robust test)

(c) Using $\operatorname{GARCH}(\mathrm{p}, \mathrm{q})$ Methodology for identifying month of the year impact in mean and variance equations

(d) TGARCH (p,q) Methodology for identifying "asymmetry in month of the year returns" with respect to positive and negative returns for the indices.

(a) Dummy OLS Regression Approach (without Intercept)

The following Models (I, II, III, IV \& V) have been developed for the Dummy Regression Approach

Model I

Return on NSE Nifty ${ }_{\mathrm{t}}=\sum_{i=1}^{12} \beta_{i} D_{i t}+\mathrm{u}_{1 \mathrm{t}}$

Model II

Return on IBOVESPA $\mathrm{t}=\sum_{i=1}^{12} \theta_{i} D_{i t}+\mathrm{u}_{2 \mathrm{t}}$ (ii)

\author{
Model III \\ Return on RTS ${ }_{\mathrm{t}}=\sum_{i=1}^{12} \Omega_{i} D_{i t}+\mathrm{u}_{3 \mathrm{t}}$ \\ (iii) \\ Model IV \\ Return on SSE Composite ${ }_{\mathrm{t}}=\sum_{i=1}^{12} \eta_{i} D_{i t}+\mathrm{u}_{4 \mathrm{t}} \ldots \ldots$ (iv) \\ Model V \\ Return on JSE TOP $40_{\mathrm{t}}==\sum_{i=1}^{12} \partial_{i} D_{i t}+\mathrm{u}_{5 \mathrm{t}}$

For Model I, Return on NSE Nifty is the Dependent variable while the independent variable is Dummy Variable qualitative in nature i.e. $D_{i t} \quad\left(D_{1 \nu} D_{2 \psi} D_{3 \nu}\right.$ $D_{4 \nu} D_{5 \psi} D_{6 \nu} D_{7 \nu} D_{8 \nu} D_{9 \nu} D_{10 \nu} D_{11 t} \& D_{12 t}$ ) are the twelve dummy variables one for each month (April to March). The regression is from the origin in the sense there is no intercept, this has been done to avoid dummy variable trap. $\mathrm{u}_{1 \mathrm{t}}$ is the error term, $\beta_{i}(i=1$ to 12) are its regression coefficients for each of the twelve months, ' $t$ ' is the time period for which the exercise is undertaken i.e. for ten years $t=1$ to 120 . The Dependent Variable (Return on NSE Nifty) is the Natural Log \& is obtained by applying the formula $\ln$. $\left(\mathrm{P}_{\mathrm{t}} / \mathrm{P}_{\mathrm{t}-1}\right)$ where $\mathrm{P}_{\mathrm{t}}$ is the monthly closing price of the NSE Nifty Index.

Using the same logic we build regression equations for Model II, III, IV\& V.

Hypothesis to be tested for Models (I, II, III,IV \& V) 
To check for the seasonal effect we establish the Null Hypothesis for each month of the year. For the first Model following shall be the Hypothesis to be tested :-

Hypothesis 1: Null :Model $\mathrm{I}_{\mathrm{O} 1}: \beta_{1}=0$, (There is no April Effect on the return of NSE Nifty )

Alternate: Model I $\mathrm{H}_{\mathrm{A} 1}: \beta_{1} \neq 0$ (There is April Effect on the return of NSE Nifty)

Hypothesis 2: Null: Model $\mathrm{I} \mathrm{H}_{\mathrm{O} 2}: \beta_{2}=0$, (There is no May Effect on the return of NSE Nifty )

Alternate: Model $\mathrm{I} \mathrm{H}_{\mathrm{A} 2}: \beta_{2} \neq 0$ (There is May Effect on the return of NSE Nifty)

Hypothesis 3: Null: Model $\mathrm{I}_{\mathrm{O} 3}: \beta_{3}=0$, (There is no June Effect on the return of NSE Nifty )

Alternate: Model $\mathrm{I} \mathrm{H}_{\mathrm{A} 3}: \beta_{3} \neq 0$ (There is June Effect on the return of NSE Nifty)

Hypothesis 4: Null: Model $\mathrm{I}_{\mathrm{O}}: \beta_{4}=0$, (There is no July Effect on the return of NSE Nifty )

Alternate: Model I $\mathrm{H}_{\mathrm{A} 4}: \beta_{4} \neq 0$ (There is July Effect on the return of NSE Nifty)

Hypothesis 5 :Null: Model $\mathrm{I}_{\mathrm{O} 5}: \beta_{5}=0$, (There is no Aug Effect on the return of NSE Nifty )

Alternate: Model I $\mathrm{H}_{\mathrm{A} 5}: \beta_{5} \neq 0$ (There is Aug Effect on the return of NSE Nifty)

Hypothesis 6: Null: Model $\mathrm{I}_{\mathrm{O}}: \beta_{6}=0$, (There is no Sep Effect on the return of NSE Nifty)

Alternate: Model $\mathrm{I}_{\mathrm{A} \sigma}: \beta_{6} \neq 0$ (There is Sep Effect on the return of NSE Nifty)

Hypothesis 7: Null: Model $\mathrm{I}_{\mathrm{O} 7}: \beta_{7}=0$, (There is no Oct Effect on the return of NSE Nifty )

Alternate: Model I $\mathrm{H}_{\mathrm{A} 7}: \beta_{7} \neq 0$ (There is Oct Effect on the return of NSE Nifty)

Hypothesis8: Null: Model $\mathrm{I}_{\mathrm{O}}: \beta_{8}=0$, (There is no Nov Effect on the return of NSE Nifty )

Alternate: Model I $\mathrm{H}_{\mathrm{A} 8}: \beta_{8} \neq 0$ (There is Nov Effect on the return of NSE Nifty)
Hypothesis 9 : Null: Model $\mathrm{I}_{\mathrm{O}}: \beta_{9}=0$, (There is no Dec Effect on the return of NSE Nifty )

Alternate: Model I $\mathrm{H}_{\mathrm{A} 9}: \beta_{9} \neq 0$ (There is Dec Effect on the return of NSE Nifty)

Hypothesis 10:Null:Model I $\mathrm{H}_{\mathrm{O} 10}: \beta_{10}=0$, (There is no Jan Effect on the return of NSE Nifty )

Alternate: Model $\mathrm{I} \mathrm{H}_{\mathrm{A} 10}: \beta_{10} \neq 0$ (There is Jan Effect on the return of NSE Nifty)

Hypothesis11:Null:Model $\mathrm{I}_{\mathrm{O} 11}: \beta_{11}=0$, (There is no Feb Effect on the return of NSE Nifty )

Alternate: Model I $\mathrm{H}_{\mathrm{A} 11}: \beta_{11} \neq 0$ (There is Feb Effect on the return of NSE Nifty)

Hypothesis11:Null:Model $\mathrm{I}_{\mathrm{O} 12}: \beta_{12}=0$, (There is no March Effect on the return of NSE Nifty )

Alternate: Model I $\mathrm{H}_{\mathrm{A} 12}: \beta_{12} \neq 0$ (There is March Effect on the return of NSE Nifty)

Again for Model II, III, IV \& V, we shall be developing our hypothesis in a similar manner

\section{(b) Hypothesis Testing using Dummy with Newey West Regression Robust approach}

It has been found that most OLS Regressions, encounter problems like serial correlation \& / or heteroscedasticity, and if the researcher fails to overcome these problems, the overall regression results get impacted which may also impact the subsequent interpretations made from the results. On the other hand a Newey West Regression tries to overcome these problems by adjusting standard errors so that they become free from these problems and therefore such Standard errors are called Heteroscedastic and Autocorrelation Consistent (HAC) Standard Errors. The results obtained from Newey West regression and its comparison with OLS results are given in Appendices.

(c) GARCH(p,q) Methodology for identifying month of the year in mean and variance equations 
GARCH Model initially developed by Engle (1992) \& later modified by Bollerslev (1986) presents an alternative method to identify the month of the year impact by removing one of the drawbacks of simple OLS Model of estimating month of the year impact. The model scores over typical OLS as it allows error terms variance to vary with time (in typical OLS, we assume error variances as constant) Thus under GARCH Methodology the error term; ut is independent and identically distributed with ' 0 ' mean but has a conditional time varying variance i.e.o2 ut. In simple language this implies that under GARCH framework one is able to check whether the variability in monthly returns over the year is consistent (some researchers also check the variability by using standard deviation). The methodology involves two steps, first is to identify whether the conditional heteroscedastic impact exists in the OLS equation and on the basis of the results develop a GARCH $(p, q)$ equation. However in our case, since the objective is to identify the conditional variability in monthly returns and not to remove the heteroscedasticity we directly develop the GARCH $(\mathrm{p}, \mathrm{q})$ equation which for our first variable. Return on NSE Nifty is given as under :

\section{MODEL A}

Ret. on NSE Nifty $t=\theta_{1}+\sum_{i=1}^{11} \beta_{i} D_{i t}+$ Ret. on NSE Nifty $t-1+$ $u_{6 t} \quad \ldots . . . . . . .(v i)$

$u_{t} \sim$ iid. $N\left(0, \sigma^{2} u_{t}\right)$

$h_{t}=\alpha_{1}+\sum_{j=1}^{p} \alpha_{2 j} \mathbf{u}^{2}{ }_{6(t-j)}+\sum_{i=1}^{q} \alpha_{3 i} h_{t-i} \ldots \ldots \ldots \ldots(\mathrm{vii})$

\section{MODEL B}

Ret. On NSE Nifty ${ }_{\mathrm{t}}=\theta_{1}+\sum_{i=1}^{11} \beta_{i} D_{i t}+$ Ret. on NSE Nifty $\mathrm{t}-1$ $+u_{6 t} \quad \ldots . . . . . . .(v i i i)$

$u_{t} \sim$ iid. $N\left(0, \sigma^{2} u_{t}\right)$

$h_{t}=\alpha_{1}+\sum_{j=1}^{p} \alpha_{2 j} u^{2} 6(t-j)+\sum_{i=1}^{q} \alpha_{3 i} h_{t-i}+\sum_{i=1}^{11} \theta_{i} D_{i t} \ldots \ldots \ldots \ldots$ (ix)

Using the same logic we build GARCH( p, q) equations for Return on IBOVESPA, Return on SSE Composite, Return on RTS \& Return on JSE TOP 40 indices.

As is clear from the above, we are incorporating two versions of $\operatorname{GARCH}(\mathrm{p}, \mathrm{q})$ in our study. Whereas MODEL A, GARCH(p,q)which has been constructed using variable return on NSE Nifty investigates the month of the year effect by including monthly dummies. MODEL B GARCH $(\mathrm{p}, \mathrm{q})$ incorporates month of the year effect through return as well as variance equations (see Karolyi (1995) \& Hsieh (1988) ). The mean equation is the same for both versions and also similar to the OLS Regression Concept, however unlike the OLS equation where there were twelve dummies, this $\operatorname{GARCH}(p, q)$ equation includes eleven dummies, the base dummy is the intercept. The variance equation on the other hand includes a Constant term, Square of the error term of previous period \& previous period's variance of the error term.

\section{(d) TGARCH $(p, q)$ Methodology for identifying asymmetry in the month of the year returns}

The GARCH (p, q) model (Model A \& Model B) discussed above were tested under the assumption that the monthly returns on our indices were 
symmetric i.e. for those months where there is a big rise in monthly average returns and for months with a big fall on average monthly returns there was an equal impact the volatility of returns, however this may not be the true always as big negative shocks due to any bad news are known to have a much higher impact the volatility than good news and therefore in order to incorporate this aspect we have applied Threshold GARCH (or ' $\mathrm{T}$ ' GARCH) model. In this model, the Threshold Dummy (DT) is added on the error term \& is supposed to take the value of 1 , if ut is negative and the value of ' 0 ' otherwise. Thus by doing so, for every bad news there would be an impact of ' $\Pi+\lambda$ ', while every good news there would be an impact of only ' $\Pi$. Also just like GARCH $(\mathrm{p}, \mathrm{q})$ methodology, here too we discuss two versions of TGARCH $(\mathrm{p}, \mathrm{q})$. Model C \& D (given below), whereas Model C does not include monthly dummies in the variance equation, Model D has a variance equation includes monthly dummies. Again both the models, Model C \& D have been constructed by considering only NSE Nifty returns as the variable, similar exercise can also be done for other indices ; Return on IBOVESPA, Return on SSE Composite, Return on RTS \& Return on JSE TOP 40.

\section{MODEL C}

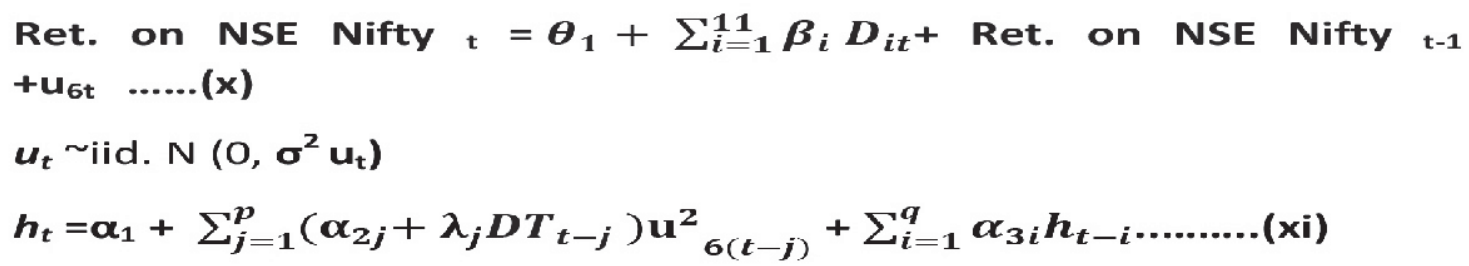

\section{Empirical Results and Interpretation}

The results of the study are given in appendices. Appendix I has a two Tables, I(a) discusses the results of the month of the year results of the BRICS nations using Dummy Variable Approach (OLS without Intercept). The results of the study clearly show that BRAZIL's IBOVESPA index has significant mean returns in the months of April (however this is only if we consider $10 \%$ as the level of significance). For the rest of the indices (India, China, S Africa \& Russia), none of the ' $p$ ' values was found to be significant showing no difference in the mean returns for different months of the year. Appendix I (b) makes a re-estimation of the OLS using the methodology adopted is Newey West which tries to make adjustment in Standard Errors by making these Heteroscedasticity and Autocorrelation Consistent (HAC) Standard Errors. The results show that mean return for BRAZIL's IBOVESPA index continued to be significantly different for the month of April while S Africa was different in its return in the month of June. For the rest of the indices (India, China \& Russia) no calendar difference in the monthly mean returns was noticed from the results.

Appendix II (a) gives the results of the GARCH $(p, q)$ with Dummies included in the mean equation as regressors. The model includes an intercept \& no. of terms of both ARCH \& GARCH have been taken as ' 1 '. The results of the model clearly show that 
Dummy is significant for BRAZIL IBOVESPA index for the month of May while for the rest of the indices there is no evidence of calendar effect in any of the rest four of the BRICS nations. Additionally the first lag of the dependent variable included as independent variable is significant at $10 \%$ for all the markets \& both the ARCH term $\left[\left(\operatorname{RESID}(-1)^{\wedge} 2\right]\right.$ and the GARCH term are significant in all the markets except Russia. Appendix II (b) gives the results of the GARCH $(\mathrm{p}, \mathrm{q})$ with Dummies included in both the mean \& variance equation as regressors, results of the mean equation shows for BRAZIL IBOVESPA's return to be different for the months of May and Nov in the mean equation while no other BRICS index showed significant difference in the dummy for any month in the mean equation. However since this table also showed the conditional volatility in the variance equation too, the month of the year effect variability in variance equation was seen in case of three economies ; S Africa in the months of June, \& March, China in the months of Sept \& Feb \& finally Brazil in the month of November.

Appendix III gives the results of TGARCH $(p, q)$ where along with regressors as Dummy Variables in mean and variance equations, the coefficient RESID $(-1)^{\wedge} 2^{*}(\operatorname{RESID}(-1)<0)$ gives the impact of bad or good news for each of our indices. Here too the ARCH \& GARCH terms are significant for all our indices for both our models given in Appendix III $(a$ \& b) i.e. first model showing dummies in mean regressors while the second includes dummies in both mean and variance regressors. The TGARCH term RESID($1)^{\wedge} 2^{*}(\operatorname{RESID}(-1)<0)$ is however significant for $S$ Africa and Brazil indices only.

Finally we have Appendix IV (I to iv) which give the results of stationarity of our variables (i.e. stock returns) which shows that all our variables are level Stationary and also do not have any trend.

\section{CONCLUSION}

The study investigated the seasonal trends in India and other BRICS nations for the period between
April 2007 to March 2017 using 'calendar effectmonth of the year' methodology. The techniques employed for testing the 'month of the year' effect included Hypothesis Testing using Dummy Approach (without intercept OLS Regression \& also with Newey West Regression Robust test), GARCH $(p, q)$ Methodology for identifying month of the year impact in mean and variance equations \& also TGARCH (p,q) Methodology for identifying "asymmetry in month of the year returns".

The study results based upon OLS Dummy without Intercept \& also based upon Newey West robust regression test showed that BRAZIL's IBOVESPA index had significant mean returns in the months of April. Significant June returns for South Africa were also noticed when Newey West was used. On the other hand $\operatorname{GARCH}(p, q)$ equation showed that BRAZIL's IBOVESPA index was significantly different in the month of May ( GARCH Model with mean regressors only) while the two months of May and Nov were significant in mean equation \& only Nov for BRAZIL IBOVESPA in variance equation (GARCH Model with regressors in both mean and variance equations). Also when regressors were included in both mean and variance equations, significant dummy was also seen in S. Africa in the months of June, \& March while China had sig. dummy in the months of Sept \& Feb. The T-GARCH term showing asymmetric volatility for good and bad news was significant for S Africa and Brazil indices only.

\section{REFERENCES}

1) Bachelier, Louis (1900)translated by A. James Boness. inCootner, P. (ed.) (1964). The Random Character of Stock Market Prices, MIT Press

2) BodlaB.S. and Jindal Kiran (2006), Seasonal Anomalies in Stock Returns: Evidence from India and the US;Decision, Volume 33(1), January-June .

3) Bollerslev, T. (1986) Generalized autoregressive conditional heteroskedasticity. Journal of econometrics, 31(3), 307-327. 
4) Chia, R. C. J., Liew, V. K. S., Wafa, S. K., \&Wafa, S. A. (2006). Calendar anomalies in the Malaysian stock market.MPRA Paper No. 516,. October (Online at http://mpra.ub.unimuenchen.de/516)

5) Chopra K et.al (2015) Empirical Test of the Random Walk Characteristics of the Stock Returns of Select South Asian Markets, Arthavaan, Vol. 1(1) pp51-57

6) Engle, R. F. (1982) Autoregressive conditional heteroscedasticity with estimates of the variance of United Kingdom inflation. Econometrica: Journal of the Econometric Society, 987-1007.

7) Exim Bank (2014), Research \& Development In BRICS: An Insight, Occasional Paper No. 168

8) Fountastilianos and N.Segredakis K, (2002)Emerging Stock Markets Return Seasonalities : The January effect and the tax-loss selling hypothesis, Applied Financial Economics, Vol 12, pp. 291-299.

9) French, K. R. (1980) Stock returns and the weekend effect. Journal of financial economics, 8(1), pp. 55-69.

10) Gibbons, M. R., \& Hess, P. (1981) Day of the week effects and asset returns. Journal of business, pp.579-596.

11) Guidi, F., Gupta, R., \&Maheshwari, S. (2011) Weak-form market efficiency and calendar anomalies for Eastern Europe equity markets. Journal of Emerging Market Finance, 10(3), pp. 337-389.

12) Hsieh, D. A. (1988) The statistical properties of daily foreign exchange rates: 1974-1983. Journal of international economics, 24(1-2), pp.129-145.

13) Ignatius Roger(1998), The Bombay Stock Exchange : Seasonalities and Investment Opportunities, Managerial Finance, Volume 24 (3), pp.52-58.

14) Jaffe, J., \&Westerfield, R. (1985 A) The week-end effect in common stock returns: the international evidence. The journal of finance, 40(2), pp. 433454.

15) Jaffe, J., \&Westerfield, R. (1985) Patterns in Japanese common stock returns: Day of the week and turn of the year effects. Journal of financial and quantitative analysis, 20(2), pp. 261-272.

16) Karolyi, G. A. (1995)A multivariate GARCH model of international transmissions of stock returns \& volatility: The case of the United States and Canada. Journal of Business \& Economic Statistics, 13(1), pp.11-25.

17) KaurHarvinder (2004), Time Varying Volatility in the Indian Stock Market, Vikalpa, Volume 29, pp. 25-42.

18) Keppler Michael and Xue Xing Hong (2003), The Seasonal Price Behaviour of Global Equity Markets, The Journal of Investing, pp. 49-53

19) Marrett, G., \& Worthington, A. (2011). The month-of-the-year effect in the Australian stock market: A short technical note on the market, industry and firm size impacts. Australasian Accounting, Business and Finance Journal,5(1), 117-123.

20) Newey, Whitney K; West, Kenneth D (1987) "A Simple, Positive Semi-definite, Heteroskedasticity and Autocorrelation Consistent Covariance Matrix". Econometrica. 55 (3): pp.703-708

21) Patel Jayen B. and Evans Dorla A(2003)., Seasonal Stock Return Patterns in the seven Industrialised Nations, The Journal of Applied Business Research, Vol. 19(3) pp. 111-120.

22) Rogalski, R. J. (1984) New findings regarding day-of-the-week returns over trading and non-trading periods: a note. The Journal of Finance, 39(5), pp.1603-1614.

23) Rozeff, M. S., \& Kinney Jr, W. R. (1976) Capital market seasonality: The case of stock returns. Journal of financial economics, 3(4), pp. 379-402.

24) Sarma S.N.(2004), Stock Market Seasonality in an emerging market, Vikalpa, Volume 29, pp. 35-41

25) Shahani R \& Ananya Sharma(2018) An Empirical Investigation into the Efficiency Parameter through Seasonal Movements in Security Prices of the BRICS nations, Paper Presented at HSB 10th Annual Conference, Hisar Feb 8-9 2018

26) Sunal, G, et.al. (2014) The Efficiency in the Indian Market in the weak form : Random Walk and Calendar Effect Investigation, India at the 
Crossroads, LexisNexisIndiapp. 95-104

27) Surbhi,PriyankaYadav, Priyanka Luthra, Pawan

Nahar \& RakeshShahani (2014) An empirical

Analysis of the 'Day of the week effect' on

Indian Market: Contemporary Issues in Leadership \& Management, Twenty First

Century Publications, India pp 157-180
28) Wilson, D., \&Purushothaman, R. (2003). Dreaming with BRICs: The path to 2050 (Vol. 99). New York, NY: Goldman, Sachs \& Company

29) Websites:

www.nseindia.com; in.finance.yahoo.com; www.jse.co.za;

\section{Appendices}

\section{Appendix I(a) : OLS results of Month of the year effect on five Sampled Indices using Dummy OLS Regression Approach (without Intercept)}

\begin{tabular}{|c|c|c|c|c|c|c|c|c|c|c|c|c|c|c|c|}
\hline \multirow[b]{2}{*}{$\begin{array}{l}\text { Month of } \\
\text { the Year } \\
\text { Dummy }\end{array}$} & \multicolumn{3}{|c|}{ S AFRICA JSE } & \multicolumn{3}{|c|}{ RUSSIA RSE } & \multicolumn{3}{|c|}{ CHINA SSE } & \multicolumn{3}{|c|}{$\begin{array}{c}\text { BRAZIL } \\
\text { IBOVESPA }\end{array}$} & \multicolumn{3}{|c|}{ INDIA NSE NIFTY } \\
\hline & $\begin{array}{c}\text { Beta } \\
\text { Coeff }\end{array}$ & $\begin{array}{l}\text { Compu } \\
\text { ted ' } t \text { ' } \\
\text { Values }\end{array}$ & $\begin{array}{c}\text { 'p' } \\
\text { Values }\end{array}$ & $\begin{array}{c}\text { Beta } \\
\text { Coeff. }\end{array}$ & $\begin{array}{l}\text { Computed } \\
\text { 't' Values }\end{array}$ & $\begin{array}{c}\text { 'p' } \\
\text { Values }\end{array}$ & $\begin{array}{l}\text { Beta } \\
\text { Coeff }\end{array}$ & $\begin{array}{l}\text { Computed } \\
\text { ' } t \text { ' Values }\end{array}$ & $\begin{array}{c}\text { 'p' } \\
\text { Values }\end{array}$ & $\begin{array}{c}\text { Beta } \\
\text { Coeff. }\end{array}$ & $\begin{array}{l}\text { Compu } \\
\text { ted 't' } \\
\text { Values }\end{array}$ & $\begin{array}{c}\text { 'p' } \\
\text { Values }\end{array}$ & $\begin{array}{l}\text { Beta } \\
\text { Coeff }\end{array}$ & $\begin{array}{l}\text { Comput } \\
\text { ed 't' } \\
\text { Values }\end{array}$ & $\begin{array}{l}\text { 'p' } \\
\text { Values }\end{array}$ \\
\hline April & 0.0125 & 0.7780 & 0.4383 & 0.0203 & 0.7254 & 0.4698 & 0.0156 & 0.5513 & 0.5826 & 0.0397 & 1.7476 & 0.0834 & 0.0229 & 0.9618 & 0.3383 \\
\hline May & 0.0162 & 1.0597 & 0.2917 & -0.0031 & -0.1165 & 0.9075 & -0.0048 & -0.1789 & 0.8584 & -0.0194 & -0.9002 & 0.3700 & 0.0259 & 1.1480 & 0.2535 \\
\hline June & -0.0211 & -1.3863 & 0.1686 & 0.0001 & 0.0039 & 0.9969 & -0.0511 & -1.8944 & 0.0609 & -0.0186 & -0.8634 & 0.3898 & -0.0054 & -0.2398 & 0.8109 \\
\hline July & 0.0133 & 0.8736 & 0.3843 & -0.0033 & -0.1251 & 0.9007 & 0.0263 & 0.9757 & 0.3314 & 0.0210 & 0.9750 & 0.3318 & 0.0178 & 0.7897 & 0.4315 \\
\hline August & -0.0047 & -0.3107 & 0.7566 & -0.0134 & -0.5068 & 0.6133 & -0.0275 & -1.0187 & 0.3107 & -0.0090 & -0.4140 & 0.6797 & -0.0091 & -0.4023 & 0.6883 \\
\hline September & -0.0045 & -0.2982 & 0.7661 & -0.0137 & -0.5184 & 0.6053 & -0.0049 & -0.1798 & 0.8576 & 0.0007 & 0.0338 & 0.9731 & 0.0287 & 1.2751 & 0.2050 \\
\hline October & 0.0220 & 1.4447 & 0.1515 & -0.0045 & -0.1714 & 0.8642 & 0.0163 & 0.6043 & 0.5470 & 0.0055 & 0.2548 & 0.7993 & -0.0106 & -0.4704 & 0.6390 \\
\hline November & -0.0016 & -0.1025 & 0.9185 & 0.0006 & 0.0233 & 0.9814 & -0.0014 & -0.0527 & 0.9581 & -0.0128 & -0.5964 & 0.5522 & -0.0038 & -0.1680 & 0.8669 \\
\hline Jan & -0.0073 & -0.4764 & 0.6348 & 0.0193 & 0.7284 & 0.4680 & -0.0345 & -1.2785 & 0.2038 & -0.0180 & -0.8340 & 0.4062 & -0.0196 & -0.8707 & 0.3859 \\
\hline Feb & 0.0088 & 0.5764 & 0.5655 & 0.0031 & 0.1157 & 0.9081 & 0.0207 & 0.7682 & 0.4441 & 0.0250 & 1.1590 & 0.2490 & -0.0066 & -0.2925 & 0.7704 \\
\hline March & 0.0185 & 1.2097 & 0.2291 & -0.0013 & -0.0493 & 0.9608 & 0.0073 & 0.2689 & 0.7885 & 0.02188 & 1.0158 & 0.3120 & 0.0301 & 1.3351 & 0.184 \\
\hline
\end{tabular}

Appendix I(b): The Newey West regression results of Month of the year effect on five Sampled Indices using Dummy Approach

\begin{tabular}{|c|c|c|c|c|c|c|c|c|c|c|c|c|c|c|c|}
\hline \multirow{2}{*}{$\begin{array}{l}\text { Month of } \\
\text { the Year } \\
\text { Dummy }\end{array}$} & \multicolumn{3}{|c|}{ S AFRICA JSE } & \multicolumn{2}{|c|}{$\begin{array}{c}\text { RUSSIA } \\
\text { RSE }\end{array}$} & \multicolumn{4}{|c|}{ CHINA SSE } & \multicolumn{3}{|c|}{$\begin{array}{c}\text { BRAZIL } \\
\text { IBOVESPA }\end{array}$} & \multicolumn{3}{|c|}{$\begin{array}{l}\text { INDIA NSE } \\
\text { NIFTY }\end{array}$} \\
\hline & $\begin{array}{l}\text { Beta } \\
\text { Coeff }\end{array}$ & $\begin{array}{l}\text { Comput } \\
\text { ed ' } t \text { ' } \\
\text { Values }\end{array}$ & $\begin{array}{l}\text { 'p' } \\
\text { Value } \\
\text { s }\end{array}$ & $\begin{array}{l}\text { Beta } \\
\text { Coeff. }\end{array}$ & $\begin{array}{l}\text { Comput } \\
\text { ed 't' } \\
\text { Values }\end{array}$ & $\begin{array}{c}\text { 'p' } \\
\text { Value } \\
s\end{array}$ & $\begin{array}{l}\text { Beta } \\
\text { Coeff }\end{array}$ & $\begin{array}{l}\text { Comput } \\
\text { ed ' } t \text { ' } \\
\text { Values }\end{array}$ & $\begin{array}{c}\text { 'p' } \\
\text { Values }\end{array}$ & $\begin{array}{c}\text { Beta } \\
\text { Coeff. }\end{array}$ & $\begin{array}{l}\text { Comput } \\
\text { ed ' } t \text { ' } \\
\text { Values }\end{array}$ & $\begin{array}{c}\text { 'p' } \\
\text { Values }\end{array}$ & $\begin{array}{l}\text { Beta } \\
\text { Coeff }\end{array}$ & $\begin{array}{l}\text { Comput } \\
\text { ed 't' } \\
\text { Values }\end{array}$ & $\begin{array}{l}\text { 'p' } \\
\text { Value } \\
\text { s }\end{array}$ \\
\hline April & 0.012512 & 1.636730 & 0.1046 & 0.0203 & 0.7878 & 0.4326 & 0.0157 & 0.6798 & 0.4981 & 0.0397 & 1.663 & 0.0993 & 0.0125 & 1.6367 & 0.1046 \\
\hline May & -0.007268 & -0.52114 & 0.6033 & -0.0031 & -0.0926 & 0.9264 & -0.0048 & -0.2641 & 0.7922 & -0.0194 & -0.7420 & 0.4597 & 0.0162 & 0.8987 & 0.3709 \\
\hline June & -0.021149 & -2.08159 & 0.0398 & 0.0001 & 0.0053 & 0.9958 & -0.0511 & -1.6151 & 0.1092 & -0.0186 & -0.9316 & 0.3536 & -0.0212 & -2.0816 & 0.0398 \\
\hline July & 0.018456 & 1.415577 & 0.1598 & -0.0033 & -0.1482 & 0.8825 & 0.0263 & 0.9611 & 0.3387 & 0.0210 & 0.9693 & 0.3346 & 0.0134 & 0.7596 & 0.4492 \\
\hline August & 0.016168 & 0.898662 & 0.3709 & -0.0134 & -0.6560 & 0.5132 & -0.0275 & -0.8585 & 0.3925 & -0.0090 & -0.5317 & 0.5961 & -0.0048 & -0.4700 & 0.6393 \\
\hline Sept & 0.008794 & 0.431844 & 0.6667 & -0.0137 & -0.3961 & 0.6928 & -0.0049 & -0.2957 & 0.7681 & 0.0007 & 0.0269 & 0.9786 & -0.0045 & -0.2060 & 0.8372 \\
\hline October & 0.013328 & 0.759556 & 0.4492 & -0.0045 & -0.1008 & 0.9199 & 0.0163 & 0.4819 & 0.6309 & 0.0055 & 0.1550 & 0.8771 & 0.0220 & 1.0156 & 0.3121 \\
\hline Nov. & -0.004740 & -0.47001 & 0.6393 & 0.0006 & 0.0357 & 0.9716 & -0.0014 & -0.0515 & 0.9590 & -0.0128 & -1.1908 & 0.2364 & -0.0016 & -0.2060 & 0.8372 \\
\hline December & -0.004549 & -0.20599 & 0.8372 & 0.0140 & 0.7512 & 0.4542 & 0.0215 & 0.8735 & 0.3843 & -0.0033 & -0.2480 & 0.8047 & 0.0076 & 0.7959 & 0.4279 \\
\hline Jan & 0.022040 & 1.015632 & 0.3121 & 0.0193 & 0.7692 & 0.4434 & -0.0345 & -0.9815 & 0.3286 & -0.0180 & -0.8783 & 0.3818 & -0.0073 & -0.5211 & 0.6033 \\
\hline Feb & -0.001564 & -0.20602 & 0.8372 & 0.0031 & 0.1682 & 0.8668 & 0.0207 & 2.3240 & 0.0220 & 0.0250 & 1.9585 & 0.0528 & 0.0088 & 0.4318 & 0.6667 \\
\hline March & 0.007570 & 0.795857 & 0.4279 & -0.0013 & -0.0543 & 0.9568 & 0.0072 & 0.2268 & 0.8210 & 0.0219 & 1.1411 & 0.2564 & 0.0185 & 1.4156 & 0.1598 \\
\hline
\end{tabular}


Appendix II(a): GARCH $(p, q)$ with Dummies included in the mean eq. as regressors

\begin{tabular}{|c|c|c|c|c|c|c|c|c|c|c|}
\hline & \multicolumn{2}{|c|}{ S AFRICA JSE } & \multicolumn{2}{|c|}{ RUSSIA RSE } & \multicolumn{2}{|c|}{ CHINA SSE } & \multicolumn{2}{|c|}{$\begin{array}{c}\text { BRAZIL } \\
\text { IBOVESPA }\end{array}$} & \multicolumn{2}{|c|}{$\begin{array}{l}\text { INDIA NSE } \\
\text { NIFTY }\end{array}$} \\
\hline & $\begin{array}{l}\text { Beta } \\
\text { Coeff }\end{array}$ & $\begin{array}{l}\text { 'p' } \\
\text { Values }\end{array}$ & $\begin{array}{l}\text { Beta } \\
\text { Coeff. }\end{array}$ & $\begin{array}{l}\text { 'p' } \\
\text { Values }\end{array}$ & $\begin{array}{l}\text { Beta } \\
\text { Coeff }\end{array}$ & $\begin{array}{l}\text { 'p' } \\
\text { Values }\end{array}$ & $\begin{array}{l}\text { Beta } \\
\text { Coeff. }\end{array}$ & $\begin{array}{l}\text { 'p' } \\
\text { Values }\end{array}$ & $\begin{array}{l}\text { Beta } \\
\text { Coeff }\end{array}$ & $\begin{array}{l}\text { 'p' } \\
\text { Values }\end{array}$ \\
\hline \multicolumn{11}{|l|}{ Mean Eq } \\
\hline $\operatorname{Ret}(-1)$ & -0.1798 & 0.0894 & 0.0303 & 0.0083 & 0.0492 & 0.0667 & 0.0404 & 0.0728 & 0.0713 & 0.0057 \\
\hline May & -0.0169 & 0.4341 & -0.0145 & 0.5593 & -0.0170 & 0.6743 & -0.0843 & 0.0003 & 0.0210 & 0.5808 \\
\hline June & -0.0169 & 0.4301 & 0.0111 & 0.7340 & -0.0358 & 0.3083 & -0.0375 & 0.1722 & 0.0026 & 0.9495 \\
\hline July & -0.0024 & 0.8993 & 0.0250 & 0.4306 & 0.0191 & 0.6179 & 0.0006 & 0.9756 & 0.0032 & 0.9445 \\
\hline August & -0.0121 & 0.5566 & -0.0011 & 0.9662 & -0.0125 & 0.7492 & -0.0153 & 0.4905 & -0.0231 & 0.5617 \\
\hline Sept & 0.0005 & 0.9768 & 0.0216 & 0.4381 & -0.0074 & 0.8409 & 0.0048 & 0.8092 & 0.0299 & 0.4299 \\
\hline October & 0.0204 & 0.3407 & 0.0260 & 0.4378 & 0.0297 & 0.4560 & 0.0067 & 0.8001 & 0.0123 & 0.7539 \\
\hline Nov. & -0.0087 & 0.7298 & 0.0146 & 0.6207 & 0.0012 & 0.9702 & -0.0401 & 0.1388 & -0.0091 & 0.8149 \\
\hline December & 0.0035 & 0.8702 & 0.0128 & 0.6417 & 0.0056 & 0.8619 & 0.0015 & 0.9480 & -0.0050 & 0.9088 \\
\hline Jan & -0.0152 & 0.4839 & 0.0112 & 0.6849 & -0.0244 & 0.5025 & -0.0384 & 0.0693 & -0.0095 & 0.7975 \\
\hline Feb & 0.0050 & 0.8041 & -0.0110 & 0.6973 & 0.0289 & 0.6866 & -0.0141 & 0.6119 & -0.0170 & 0.6546 \\
\hline March & -0.0014 & 0.9474 & -0.0014 & 0.9585 & 0.0010 & 0.9767 & -0.0082 & 0.6798 & 0.0318 & 0.4156 \\
\hline \multicolumn{11}{|l|}{ Var. Eq. } \\
\hline$\overline{\operatorname{RESID}(-1)^{\wedge} 2}$ & 0.4111 & 0.0482 & 0.3742 & 0.0307 & 0.1702 & 0.1543 & 0.5198 & 0.0033 & 0.2430 & 0.0357 \\
\hline GARCH(-1) & 0.5465 & 0.0016 & 0.5059 & 0.0030 & 0.7815 & 0.0000 & -0.0442 & 0.0878 & 0.7409 & 0.0000 \\
\hline
\end{tabular}

\section{Appendix II(b): GARCH $(p, q)$ with Dummies included in the mean $\mathcal{E}$ variance as} regressors

\begin{tabular}{|c|c|c|c|c|c|c|c|c|c|c|}
\hline & \multicolumn{2}{|c|}{$\begin{array}{l}\text { S AFRICA } \\
\text { JSE }\end{array}$} & \multicolumn{2}{|c|}{ RUSSIA RSE } & \multicolumn{2}{|c|}{ CHINA SSE } & \multicolumn{2}{|c|}{$\begin{array}{c}\text { BRAZIL } \\
\text { IBOVESPA }\end{array}$} & \multicolumn{2}{|c|}{$\begin{array}{l}\text { INDIA NSE } \\
\text { NIFTY }\end{array}$} \\
\hline & $\begin{array}{l}\text { Beta } \\
\text { Coeff }\end{array}$ & $\begin{array}{l}\text { 'p' } \\
\text { Values }\end{array}$ & $\begin{array}{l}\text { Beta } \\
\text { Coeff. }\end{array}$ & $\begin{array}{l}\text { 'p' } \\
\text { Values }\end{array}$ & $\begin{array}{l}\text { Beta } \\
\text { Coeff }\end{array}$ & $\begin{array}{l}\text { 'p' } \\
\text { Values }\end{array}$ & $\begin{array}{l}\text { Beta } \\
\text { Coeff. }\end{array}$ & \begin{tabular}{|l|} 
'p' \\
Values
\end{tabular} & $\begin{array}{l}\text { Beta } \\
\text { Coeff }\end{array}$ & $\begin{array}{l}\text { 'p' } \\
\text { Values }\end{array}$ \\
\hline \multicolumn{11}{|l|}{ Mean Eq } \\
\hline $\operatorname{Ret}(-1)$ & -0.0514 & 0.0653 & -0.0195 & 0.0162 & 0.1435 & 0.0203 & 0.120769 & 0.0365 & 0.0591 & 0.0062 \\
\hline May & -0.0030 & 0.9458 & -0.0467 & 0.3958 & -0.0279 & 0.6098 & -0.075782 & 0.0191 & 0.0156 & 0.7692 \\
\hline June & -0.0186 & 0.6553 & 0.015 & 0.7518 & -0.0570 & 0.3379 & -0.027391 & 0.4357 & -0.0215 & 0.7032 \\
\hline July & -0.0071 & 0.8695 & 0.0043 & 0.9243 & 0.0111 & 0.8560 & -0.016020 & 0.6481 & 0.0070 & 0.8772 \\
\hline Aug & -0.0221 & 0.5956 & -0.0282 & 0.5818 & -0.0536 & 0.3495 & -0.060397 & 0.1103 & -0.0310 & 0.5329 \\
\hline Sept & -0.0110 & 0.8075 & -0.0024 & 0.9604 & -0.0187 & 0.7291 & -0.000620 & 0.9874 & 0.0183 & 0.7247 \\
\hline Oct & 0.0110 & 0.8049 & 0.0063 & 0.8941 & 0.0054 & 0.9379 & -0.005662 & 0.9131 & -0.0299 & 0.6452 \\
\hline Nov. & -0.0151 & 0.7192 & -0.0040 & 0.9344 & -0.0062 & 0.9191 & -0.054270 & 0.0809 & -0.0246 & 0.5613 \\
\hline Dec & -0.0046 & 0.9123 & -0.0063 & 0.9024 & 0.0033 & 0.9559 & -0.025585 & 0.4120 & -0.0137 & 0.7647 \\
\hline Jan & -0.0177 & 0.6809 & -0.0042 & 0.9393 & -0.0775 & 0.1609 & -0.047493 & 0.2583 & -0.0380 & 0.4449 \\
\hline Feb & -0.0005 & 0.9916 & -0.0260 & 0.6146 & 0.0176 & 0.7361 & 0.000625 & 0.9843 & -0.0262 & 0.5972 \\
\hline March & 0.0024 & 0.9541 & -0.0311 & 0.5198 & -0.0091 & 0.8717 & -0.010548 & 0.7674 & 0.0142 & 0.7643 \\
\hline & & & & & & & & & & \\
\hline \multicolumn{11}{|l|}{ VarEq } \\
\hline $\begin{array}{l}\text { RESID(-1) } \\
\wedge_{2}\end{array}$ & 0.0944 & 0.0359 & 0.2162 & 0.0136 & 0.0560 & 0.0302 & 0.067144 & 0.0274 & 0.0605 & 0.5614 \\
\hline GARCH(-1) & 0.5905 & 0.0190 & 0.6488 & 0.0002 & 0.6164 & 0.0140 & 0.671315 & 0.0000 & 0.5746 & 0.1785 \\
\hline May & -0.0005 & 0.8806 & -0.0041 & 0.7548 & -0.0096 & 0.0004 & 0.002202 & 0.8172 & -0.0001 & 0.9881 \\
\hline June & -0.0026 & 0.0868 & -0.0061 & 0.4267 & 0.0009 & 0.8613 & -0.004128 & 0.4268 & -0.0040 & 0.5033 \\
\hline July & -0.0005 & 0.4930 & -0.0065 & 0.4041 & -0.0053 & 0.3031 & -0.002643 & 0.5441 & -0.0054 & 0.3305 \\
\hline Aug & -0.0027 & 0.2227 & -0.0032 & 0.6791 & -0.0040 & 0.3554 & -0.004047 & 0.2048 & -0.0037 & 0.4910 \\
\hline Sept & 0.0013 & 0.4989 & -0.0042 & 0.6020 & -0.0073 & 0.0195 & 0.002152 & 0.6671 & -0.0003 & 0.9587 \\
\hline
\end{tabular}


Appendix III(a): TGARCH $(p, q)$ with Dummies included in the mean eq. as regressors

\begin{tabular}{|c|c|c|c|c|c|c|c|c|c|c|}
\hline & \multicolumn{2}{|c|}{$\begin{array}{l}\text { S AFRICA } \\
\text { JSE }\end{array}$} & \multicolumn{2}{|c|}{ RUSSIA RSE } & \multicolumn{2}{|c|}{ CHINA SSE } & \multicolumn{2}{|c|}{$\begin{array}{c}\text { BRAZIL } \\
\text { IBOVESPA }\end{array}$} & \multicolumn{2}{|c|}{$\begin{array}{c}\text { INDIA NSE } \\
\text { NIFTY }\end{array}$} \\
\hline & $\begin{array}{l}\text { Beta } \\
\text { Coeff }\end{array}$ & $\begin{array}{l}\text { 'p' } \\
\text { Values }\end{array}$ & $\begin{array}{l}\text { Beta } \\
\text { Coeff. }\end{array}$ & $\begin{array}{l}\text { 'p' } \\
\text { Values }\end{array}$ & $\begin{array}{l}\text { Beta } \\
\text { Coeff }\end{array}$ & $\begin{array}{l}\text { 'p' } \\
\text { Values }\end{array}$ & $\begin{array}{l}\text { Beta } \\
\text { Coeff. }\end{array}$ & $\begin{array}{l}\text { 'p' } \\
\text { Values }\end{array}$ & $\begin{array}{l}\text { Beta } \\
\text { Coeff }\end{array}$ & $\begin{array}{l}\text { 'p' } \\
\text { Values }\end{array}$ \\
\hline \multicolumn{11}{|l|}{ Mean Eq } \\
\hline Ret(-1) & -0.0461 & 0.0682 & 0.0288 & 0.0784 & 0.08761 & 0.0334 & 0.1706 & 0.0669 & 0.0562 & 0.0666 \\
\hline May & -0.0186 & 0.1934 & -0.0223 & 0.4730 & -0.0202 & 0.5704 & -0.0675 & 0.0002 & 0.0179 & 0.6524 \\
\hline June & -0.0352 & 0.0064 & 0.0074 & 0.8124 & -0.0161 & 0.5995 & -0.0643 & 0.7022 & 0.0010 & 0.9809 \\
\hline July & -0.0130 & 0.3697 & 0.0111 & 0.7161 & 0.0047 & 0.8816 & 0.0008 & 0.9653 & 0.0042 & 0.9311 \\
\hline August & -0.0293 & 0.1384 & -0.0053 & 0.8471 & -0.0219 & 0.4766 & -0.0244 & 0.5242 & -0.0216 & 0.6061 \\
\hline Sept & -0.0155 & 0.2019 & 0.0151 & 0.6007 & -0.0200 & 0.5719 & -0.0335 & 0.4980 & 0.0295 & 0.4588 \\
\hline October & 0.0239 & 0.2084 & 0.0307 & 0.3955 & 0.0144 & 0.6987 & -0.0041 & 0.0803 & 0.0110 & 0.7887 \\
\hline Nov. & -0.0255 & 0.1060 & 0.0291 & 0.3404 & 0.0128 & 0.6891 & -0.0600 & 0.0323 & -0.0087 & 0.8302 \\
\hline Dec & -0.0061 & 0.6707 & 0.0253 & 0.3780 & -0.0060 & 0.8305 & -0.0338 & 0.2326 & -0.0020 & 0.9638 \\
\hline Jan & -0.0298 & 0.0556 & 0.0123 & 0.6849 & -0.0022 & 0.9468 & -0.0701 & 0.2444 & -0.0167 & 0.6698 \\
\hline Feb & -0.0066 & 0.6404 & -0.0157 & 0.5903 & 0.0082 & 0.0890 & -0.0003 & 0.9919 & -0.0183 & 0.6454 \\
\hline March & -0.0101 & 0.5615 & -0.0052 & 0.8631 & 0.0269 & 0.3865 & -0.0141 & 0.4104 & 0.0275 & 0.5068 \\
\hline \multicolumn{11}{|l|}{ VarEq } \\
\hline $\operatorname{RESID(-1)^{\wedge }2}$ & -0.1815 & 0.0440 & -0.0185 & 0.0907 & 0.1017 & 0.0000 & -0.1638 & 0.0390 & 0.1664 & 0.0174 \\
\hline $\begin{array}{c}\text { RESID(- } \\
12^{\wedge} 2^{*}(\operatorname{RESID}(- \\
\left.1)^{2}<0\right)\end{array}$ & 0.9290 & 0.0111 & 0.5066 & 0.0760 & -0.1949 & 0.0000 & 0.4611 & 0.0049 & 0.1291 & 0.3436 \\
\hline GARCH(-1) & 0.6726 & 0.0000 & 0.6827 & 0.0000 & 1.0387 & 0.0000 & 0.6410 & 0.0000 & 0.7309 & 0.0000 \\
\hline
\end{tabular}

Appendix III(b): TGARCH $(p, q)$ with Dummies included in the mean $\mathcal{E}$ variance eq. as regressors

\begin{tabular}{|c|c|c|c|c|c|c|c|c|c|c|}
\hline & \multicolumn{2}{|c|}{$\begin{array}{c}\text { S AFRICA } \\
\text { JSE }\end{array}$} & \multicolumn{2}{|c|}{$\begin{array}{c}\text { RUSSIA } \\
\text { RSE }\end{array}$} & \multicolumn{2}{|c|}{$\begin{array}{c}\text { CHINA } \\
\text { SSE }\end{array}$} & \multicolumn{2}{|c|}{$\begin{array}{c}\text { BRAZIL } \\
\text { IBOVESPA }\end{array}$} & \multicolumn{2}{|c|}{$\begin{array}{l}\text { INDIA NSE } \\
\text { NIFTY }\end{array}$} \\
\hline & $\begin{array}{l}\text { Beta } \\
\text { Coeff }\end{array}$ & $\begin{array}{l}\text { 'p' } \\
\text { Value }\end{array}$ & $\begin{array}{l}\text { Beta } \\
\text { Coeff. }\end{array}$ & $\begin{array}{l}\text { 'p' } \\
\text { Values }\end{array}$ & $\begin{array}{l}\text { Beta } \\
\text { Coeff }\end{array}$ & $\begin{array}{l}\text { 'p' } \\
\text { Values }\end{array}$ & $\begin{array}{l}\text { Beta } \\
\text { Coeff. }\end{array}$ & $\begin{array}{l}\text { 'p' } \\
\text { Values }\end{array}$ & $\begin{array}{l}\text { Beta } \\
\text { Coeff }\end{array}$ & $\begin{array}{l}\text { 'p' } \\
\text { Values }\end{array}$ \\
\hline \multicolumn{11}{|l|}{ Mean Eq } \\
\hline $\operatorname{Ret}(-1)$ & -0.1522 & 0.0278 & -0.0242 & 0.0837 & 0.1766 & 0.0742 & 0.1404 & 0.0311 & 0.0734 & 0.0597 \\
\hline May & -0.0126 & 0.7837 & -0.0476 & 0.3501 & -0.0281 & 0.6081 & -0.0726 & 0.0931 & 0.0176 & 0.7077 \\
\hline June & 0.0033 & 0.0937 & 0.0027 & 0.9476 & -0.0616 & 0.3043 & -0.0491 & 0.2091 & -0.0194 & 0.7234 \\
\hline July & -0.003 & 0.9339 & 0.0042 & 0.9244 & 0.0139 & 0.8186 & -0.0138 & 0.7087 & 0.0032 & 0.9468 \\
\hline August & -0.0140 & 0.7325 & -0.0283 & 0.5545 & -0.0532 & 0.3617 & -0.0430 & 0.2447 & -0.0338 & 0.4632 \\
\hline Sept & -0.0054 & 0.9000 & -0.0032 & 0.9440 & -0.0156 & 0.7713 & 0.0087 & 0.8405 & 0.0201 & 0.6897 \\
\hline October & -0.0237 & 0.5675 & 0.0110 & 0.8069 & 0.0013 & 0.9835 & -0.0065 & 0.8661 & -0.0273 & 0.5955 \\
\hline Nov. & -0.0036 & 0.9274 & -0.0038 & 0.9313 & -0.0046 & 0.9412 & -0.0543 & 0.0175 & -0.0308 & 0.5331 \\
\hline Dec & 0.0161 & 0.7047 & -0.0009 & 0.9844 & 0.0021 & 0.9738 & -0.0171 & 0.6026 & -0.0165 & 0.7202 \\
\hline Jan & -0.0120 & 0.7753 & -0.0028 & 0.9584 & -0.0584 & 0.2893 & -0.0560 & 0.2129 & -0.0415 & 0.4228 \\
\hline Feb & -0.0005 & 0.9886 & -0.0288 & 0.5635 & 0.0156 & 0.7600 & -0.0103 & 0.7622 & -0.0327 & 0.5165 \\
\hline March & -0.0133 & 0.7587 & -0.0279 & 0.5361 & -0.0069 & 0.9009 & -0.0200 & 0.5951 & 0.0121 & 0.8100 \\
\hline \multicolumn{11}{|l|}{ Var. Eq } \\
\hline $\operatorname{RESID(-1)^{\wedge }2}$ & 0.0685 & 0.0741 & 0.1436 & 0.0383 & 0.0429 & 0.0411 & -0.0094 & 0.0900 & 0.0747 & 0.0596 \\
\hline
\end{tabular}


Table IV (I) :Test for stationarity for NSE Nifty

Null Hypothesis (1): RETURN NSE Nifty has a unit root

Null Hypothesis (2) : RETURN NSE Nifty has no trend

Computed

'p'Value.

\begin{tabular}{|l|l|c|c|}
\hline Level & ADF test 't' statistic & $\mathbf{- 9 . 8 9 5 5 5 2}$ & $\mathbf{0 . 0 0 0 0}$ \\
& @TREND & $\mathbf{0 . 3 0 5 4 7 7}$ & $\mathbf{0 . 7 6 0 6}$ \\
\hline
\end{tabular}

Table IV (ii) :Test for stationarity for SSE Composite Index

Null Hypothesis (1): RETURNSSE Composite Index has a unit root

Null Hypothesis (2) : RETURNSSE Composite Index has no trend

\begin{tabular}{|l|l|c|c|}
\multicolumn{2}{|c|}{ Computed t } & 'p' Value. \\
\hline Level & ADF test 't' statistic & -9.819160 & $\mathbf{0 . 0 0 0 0}$ \\
& @TREND & $\mathbf{0 . 9 1 0 2 5 8}$ & $\mathbf{0 . 3 6 4 6}$ \\
& & & \\
\hline
\end{tabular}

Table IV (iii) :Test for stationarity for Russian Trading Stock (RTS))

\begin{tabular}{|c|c|c|c|}
\hline \multicolumn{4}{|c|}{$\begin{array}{l}\text { Null Hypothesis (1): RETURNRTS Index has a unit root } \\
\text { Null Hypothesis (2) : RETURNRTS Index has no trend }\end{array}$} \\
\hline Level & $\begin{array}{l}\text { ADF test ' } \mathrm{t} \text { ' statistic } \\
\text { @TREND }\end{array}$ & $\begin{array}{r}-7.776595 \\
0.327591\end{array}$ & $\begin{array}{r}\mathbf{0 . 0 0 0 0} \\
\mathbf{0 . 7 4 3 8}\end{array}$ \\
\hline
\end{tabular}

Table IV (iv) :Test for stationarity for IBOVESPA

\begin{tabular}{|c|c|c|c|}
\hline \multicolumn{4}{|c|}{$\begin{array}{l}\text { Null Hypothesis (1): RETURNIBOVESPA Index has a unit root } \\
\text { Null Hypothesis (2) : RETURNIBOVESPA Index has no trend }\end{array}$} \\
\hline & & Computed $t$ & 'p'Value. \\
\hline Level & $\begin{array}{l}\text { ADF test ' } \mathrm{t} \text { ' statistic } \\
\text { @TREND }\end{array}$ & $\begin{array}{r}-9.022813 \\
0.201734\end{array}$ & $\begin{array}{l}\mathbf{0 . 0 0 0 0} \\
\mathbf{0 . 8 4 0 5}\end{array}$ \\
\hline
\end{tabular}

Table IV (v) :Test of stationarity for FTSE/JSE Top 40 Index

Null Hypothesis (1): RETURNFTSE/JSE Top 40 Index has a unit root

Null Hypothesis (2) : RETURNFTSE/JSE Top 40 Index has no trend

\begin{tabular}{|c|c|c|c|}
\hline & & Computed $t$ & 'p'Value. \\
\hline Level & $\begin{array}{l}\text { ADF test statistic } \\
\text { @ TREND }\end{array}$ & $\begin{array}{l}-8.201734 \\
0.355638\end{array}$ & $\begin{array}{l}0.0000 \\
0.7228\end{array}$ \\
\hline
\end{tabular}

